Rapp. Grønlands geol. Unders. 66, 32-38 (1974)

\title{
THE GEOCHRONOLOGY OF THE SCORESBY SUND AREA, CENTRAL EAST GREENLAND
}

Progress report 6: $\mathrm{Rb} / \mathrm{Sr}$ whole rock and $\mathrm{U}-\mathrm{Pb}$ zircon ages

\section{B. T. Hansen, F. Oberli and R. H. Steiger.}

The age determination programme on rocks from the Caledonian fold belt of East Greenland has been continued at the Eidg. Technische Hochschule in Zürich. Recent work has been aimed at verification of the pre-Caledonian age for an early metamorphism of the Krummedal supracrustal sequence. Additional analyses on further rock samples of this sequence have clearly confirmed that a strong preCaledonian metamorphism affected the rocks of the Scoresby Sund area around 1000 to $1200 \mathrm{~m} . y$. ago. This pre-Caledonian event is also reflected by the ages of three synkinematic granitic bodies in Nordvestfjord, Øfjord and on Bjørneøer.

\section{Interpretation}

The tentative interpretations put forward below are based on the geological descriptions of the Scoresby Sund area given by Henriksen \& Higgins (1971) and others, as well as personal communications with GGU staff geologists.

A subdivision of the Krummedal sequence into three main groups was made on the basis of their metamorphic and geographical relations and is shown in table 6. The intrusive rock types are listed in table 7.

\section{Krummedal supracrustal sequence}

1a. Kyanite-bearing garnet schists from Gaiseland, Paul Stern Land, Rolige Bra and Renodden

All samples from this southern region plot on an isochron with a slope corresponding to an age of $1162 \pm 85$ m.y. (fig. 7), which appears to reflect the time of an early metamorphism of the Krummedal supracrustal sequence. A biotite 
Table 6. Preliminary $\mathrm{Rb} / \mathrm{Sr}$ whole-rock ages from the Krummedal supracrustal sequence

\begin{tabular}{|c|c|c|c|c|c|}
\hline \multicolumn{3}{|c|}{ GGU sample no. Location } & $\begin{array}{l}\text { Coordinate position } \\
70^{\circ} 09^{\prime} 01^{\prime \prime} \mathrm{N} / 28^{\circ} 39^{\prime} 05^{\prime \prime} \mathrm{W}\end{array}$ & $\begin{array}{l}\text { Rock type } \\
\text { mica schist }\end{array}$ & $\begin{array}{l}\mathrm{Rb} / \mathrm{Sr} \\
\mathrm{age} \times 10^{6} \mathrm{y} .\end{array}$ \\
\hline (1a) & $\begin{array}{l}166905 \\
166908 \\
166887 \\
166888 \\
166898 \\
166899 \\
166862\end{array}$ & $\begin{array}{l}\text { Vindblæsdal } \\
\text { Vindblæsdal } \\
\text { Paul Stern Land } \\
\text { Paul Stern Land } \\
\text { Rolige Bræ } \\
\text { Rolige Bræ } \\
\text { Renodden }\end{array}$ & $\begin{array}{l}70^{\circ} 09^{\prime} 01^{\prime \prime} \mathrm{N} / 28^{\circ} 39^{\prime} 05^{\prime \prime} \mathrm{W} \\
70^{\circ} 09^{\prime} 22^{\prime \prime} \mathrm{N} / 28^{\circ} 39^{\prime} 24^{\prime \prime} \mathrm{W} \\
70^{\circ} 20^{\prime} 45^{\prime \prime} \mathrm{N} / 29^{\circ} 27^{\prime} 27^{\prime \prime} \mathrm{W} \\
70^{\circ} 20^{\prime} 58^{\prime \prime} \mathrm{N} / 29^{\circ} 26^{\prime} 53^{\prime \prime} \mathrm{W} \\
70^{\circ} 36^{\prime} 37^{\prime \prime} \mathrm{N} / 28^{\circ} 32^{\prime} 13^{\prime \prime} \mathrm{W} \\
70^{\circ} 36^{\prime} 37^{\prime \prime} \mathrm{N} / 28^{\circ} 32^{\prime} 13^{\prime \prime} \mathrm{W} \\
70^{\circ} 28^{\prime} \quad \mathrm{N} / 28^{\circ} 19^{\prime}\end{array}$ & $\begin{array}{l}\text { mica schist } \\
\text { mica schist } \\
\text { mica schist } \\
\text { mica schist } \\
\text { mica schist } \\
\text { mica schis. } \\
\text { mica schist }\end{array}$ & ) \\
\hline & $\begin{array}{l}166906 \\
166907\end{array}$ & $\begin{array}{l}\text { Vindblæsdal } \\
\text { Vindblæsdal }\end{array}$ & $\begin{array}{l}70^{\circ} 09^{\prime} 06^{\prime \prime} \mathrm{N} / 28^{\circ} 39^{\prime} 09^{\prime \prime} \mathrm{W} \\
70^{\circ} 09^{\prime} 12^{\prime \prime} \mathrm{N} / 28^{\circ} 39^{\prime} 28^{\prime \prime} \mathrm{W}\end{array}$ & $\begin{array}{l}\text { musc pegmatite } \\
\text { musc pegmatite }\end{array}$ & $907 \pm 250$ \\
\hline (1b) & $\begin{array}{l}166861 \\
166862\end{array}$ & $\begin{array}{l}\text { Harefjord } \\
\text { Harefjord }\end{array}$ & $\begin{array}{l}70^{\circ} 54^{\prime} 43^{\prime \prime} \mathrm{N} / 28^{\circ} 11^{\prime} 53^{\prime \prime} \mathrm{W} \\
70^{\circ} 54^{\prime} 43^{\prime \prime} \mathrm{N} / 28^{\circ} 11^{\prime} 53^{\prime \prime} \mathrm{W}\end{array}$ & $\begin{array}{l}\text { mica schist } \\
\text { mica schist }\end{array}$ & $900 \pm 7$ \\
\hline & $\begin{array}{l}166863 \\
166864\end{array}$ & $\begin{array}{l}\text { Harefjord } \\
\text { Harefjord }\end{array}$ & $\begin{array}{l}70^{\circ} 55^{\prime} 19^{\prime \prime} \mathrm{N} / 28^{\circ} 15^{\prime} 54^{\prime \prime} \mathrm{W} \\
70^{\circ} 55^{\prime} 19^{\prime \prime} \mathrm{N} / 28^{\circ} 15^{\prime} 54^{\prime \prime} \mathrm{W}\end{array}$ & $\begin{array}{l}\text { mica schist } \\
\text { mica schist }\end{array}$ & $954 \pm 45$ \\
\hline (1c) & $\begin{array}{l}166812 \\
166814\end{array}$ & $\begin{array}{l}\text { Krummedal } \\
\text { Krummedal }\end{array}$ & $\begin{array}{l}71^{\circ} 25^{\prime} 28^{\prime \prime} \mathrm{N} / 29^{\circ} 14^{\prime} 37^{\prime \prime} \mathrm{W} \\
71^{\circ} 25^{\prime} 28^{\prime \prime} \mathrm{N} / 29^{\circ} 14^{\prime} 37^{\prime \prime} \mathrm{W}\end{array}$ & $\begin{array}{l}\text { mica schist } \\
\text { mica schist }\end{array}$ & $445 \pm 9$ \\
\hline
\end{tabular}

Table 7. Location of analysed igneous rocks from the central Scoresby Sund area

(2a) 101777 Bjørneøer, island no. $1 \quad 71^{\circ} 10^{\prime} 11^{\prime \prime} \mathrm{N} / 25^{\circ} 19^{\prime} 11^{\prime \prime} \mathrm{W}$ granodiorite

112603 Bjørneøer, island no. $171^{\circ} 08^{\prime} 44^{\prime \prime} \mathrm{N} / 25^{\circ} 20^{\prime} 56^{\prime \prime} \mathrm{W}$ monzogranite

112669 Bjørneøer, island no. $17^{\circ} 09^{\prime} 14^{\prime \prime} \mathrm{N} / 25^{\circ} 21^{\prime} 41^{\prime \prime} \mathrm{W}$ granodiorite grey granite

112672 Bjørneøer, island no. $1 \quad 71^{\circ} 08^{\prime} 29^{\prime \prime} \mathrm{N} / 25^{\circ} 21^{\prime} 54^{\prime \prime} \mathrm{W}$ granodiorite

(2b) 10381

North coast of

$71^{\circ} 31^{\prime} \quad \mathrm{N} / 25^{\circ} 44^{\prime} \quad \mathrm{W}$ foliated augen granite Nordvestfjord

136611 South coast of Øfjord $70^{\circ} 53^{\prime} 50^{\prime \prime} \mathrm{N} / 26^{\circ} 33^{\prime} 30^{\prime \prime} \mathrm{W}$ foliated augen granite

$\mathrm{Rb} / \mathrm{Sr}$ determination on another sample from this area gives a Caledonian age (Hansen et al., 1973) demonstrating a Caledonian overprinting of this area. However, the Caledonian metamorphism was not strong enough to reset the wholerock $\mathrm{Rb}-\mathrm{Sr}$ system.

In addition two samples from pegmatitic veins were analysed (open dots in fig. 7). They yield an apparent age of some $900 \mathrm{~m} . \mathrm{y}$. in good agreement with the 


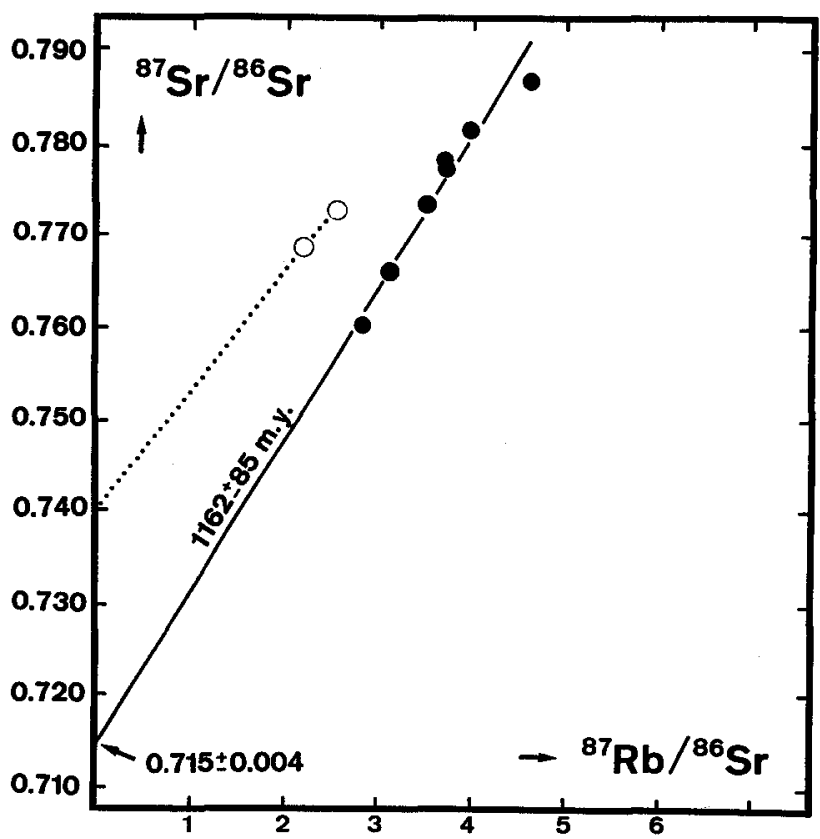

Fig. 7. $\mathrm{Rb} / \mathrm{Sr}$ evolution diagram for whole-rock samples listed in table 6 under la. Solid dots represent mica schists. Open dots represent muscovite pegmatites. $\lambda{ }^{87} \mathrm{Rb}=1.39 \times 10^{-11} \mathrm{y}^{-1}$.

field evidence that they are discordant to the schistosity of the country rock and that they are folded by a later tectonic event, probably during the Caledonian orogeny.

\section{1b. Kyanite-bearing mica schists from Harefjord}

At two localities in Harefjord we have collected pairs of samples, within a distance of 10 metres of each other. The two 'two-point-isochrons' (fig. 8) show ages of some 900 m.y. The rocks may have been open systems with respect to $\mathrm{Rb}-\mathrm{Sr}$ during the Caledonian orogeny but the metamorphism was not strong enough for a complete $\mathrm{Sr}$ homogenisation of the whole-rock system.

\section{1c. Calcareous mica schists in Krummedal}

The two rock samples from Krummedal were collected within the same outcrop and plot on a line with a slope corresponding to $445 \mathrm{~m}$.y. (fig. 8). We interpret 
this as a complete resetting of the $\mathrm{Rb}-\mathrm{Sr}$ whole-rock system during Caledonian time and furthermore as evidence for a progressive Caledonian metamorphism from south to north within the Krummedal supracrustal sequence.

\section{Igneous rocks from the central Scoresby Sund area}

\section{2a. Grey granite sheet from island no. 1 of Biørneøer}

A preliminary whole-rock isochron based on four rock samples of about $15 \mathrm{~kg}$ collected from different localities within the granodiorite yields an age of $1060 \pm 40$ m.y. (fig. 9). This age may correspond to the age of emplacement of the 'grey granite' (Oberli \& Steiger, 1973) or, alternatively, reflect the time of Sr isotope homogenisation during a high-grade metamorphic overprint of the rocks. Because of the small spread of the three data points with the lower ${ }^{87} \mathrm{Sr} /{ }^{86} \mathrm{Sr}$ ratios, which belong to samples from the inner part of the sheet (GGU 101777, GGU 112669, GGU 112672) the isochron is essentially dominated by the data point of the rock sample (GGU 112603) collected close to the contact with the migmatites.

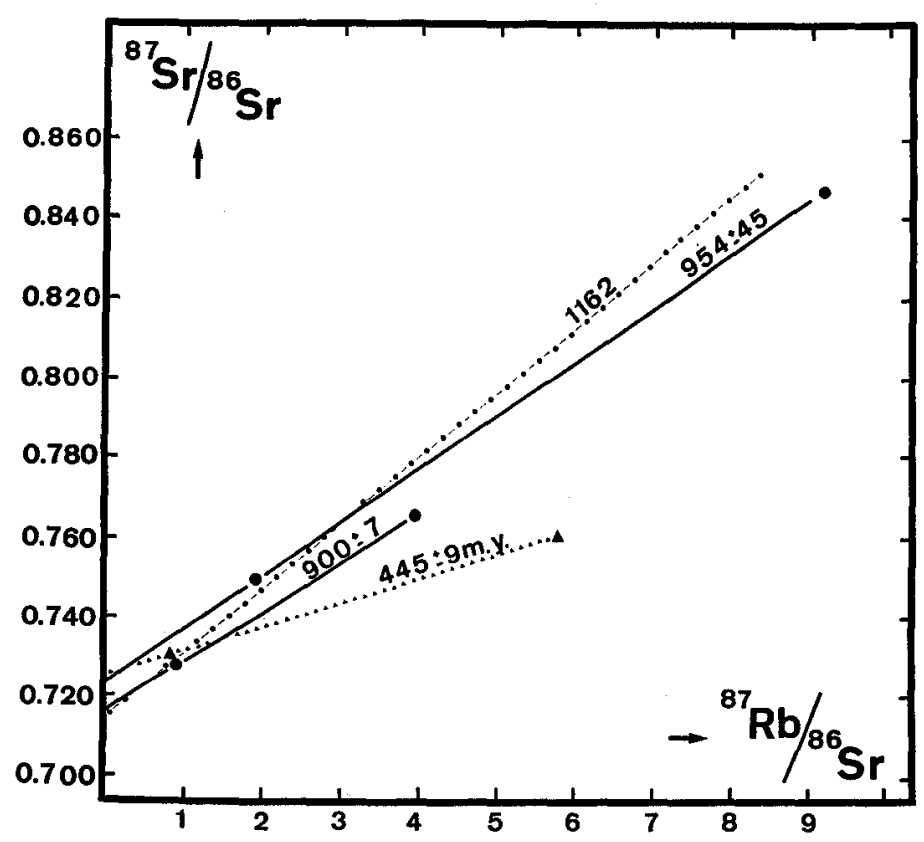

Fig. 8. $\mathrm{Rb} / \mathrm{Sr}$ evolution diagram for whole-rock samples listed in table 6 under $1 \mathrm{~b}$ and $1 \mathrm{c}$. Solid dots represent mica schists from Harefjord. Triangles represent mica schists from Krummedal. The dashed-dotted line $(1162 \mathrm{~m} . \mathrm{y}$.) corresponds to the solid isochron shown in fig. 7. $\lambda^{87} \mathrm{Rb}=1.39 \times 10^{-11} \mathrm{y}^{-1}$. 


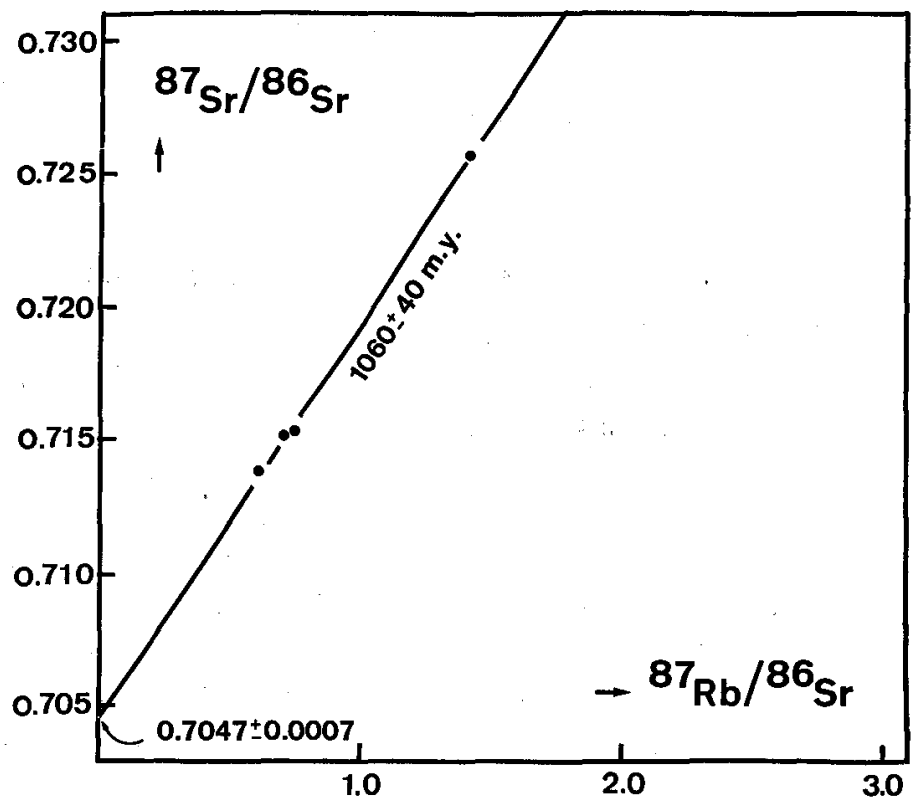

Fig. 9. $\mathrm{Rb} / \mathrm{Sr}$ evolution diagram for whole-rock samples from 'grey granite' listed in table 7 . $\lambda{ }^{87} \mathrm{Rb}=1.39 \times 10^{-11} \mathrm{y}^{-1}$.

$2 b$. Augen granites from the north coast of Nordvestfjord and south coast of Øfjord

Sample GGU 136611 from Øfjord is a foliated garnet augen granite from a body similar to that of the foliated augen granite GGU 103811 from the north coast of Nordvestfjord. Geologically these augen granites are early sheet-like intrusions, which were metamorphosed synkinematically under a regional metamorphism corresponding to sillimanite grade (see also Chadwick, 1971).

While the four zircon fractions from GGU 103811 (for details see Steiger \& Henriksen, 1972) plot in a cluster on the concordia diagram (fig. 10) the new data for GGU 136611 show a much better spread in the U-Pb ratios. The individual data points represent selected $5-20 \mathrm{mg}$ fractions of extreme physical properties which were separated from a zircon concentrate weighing $31 \mathrm{~g}$.

The zircon fractions of GGU 136611 with high ${ }^{207} \mathrm{~Pb} /{ }^{206} \mathrm{~Pb}$ ages plot on the same 950 m.y. Tilton diffusion curve (Tilton, 1960) which also passes through the cluster of data points of GGU 103811. We assume that these zircons were formed during the intrusion of the augen granites, at least 950 m.y. ago, while those fractions which plot above the diffusion line were affected by later events. 


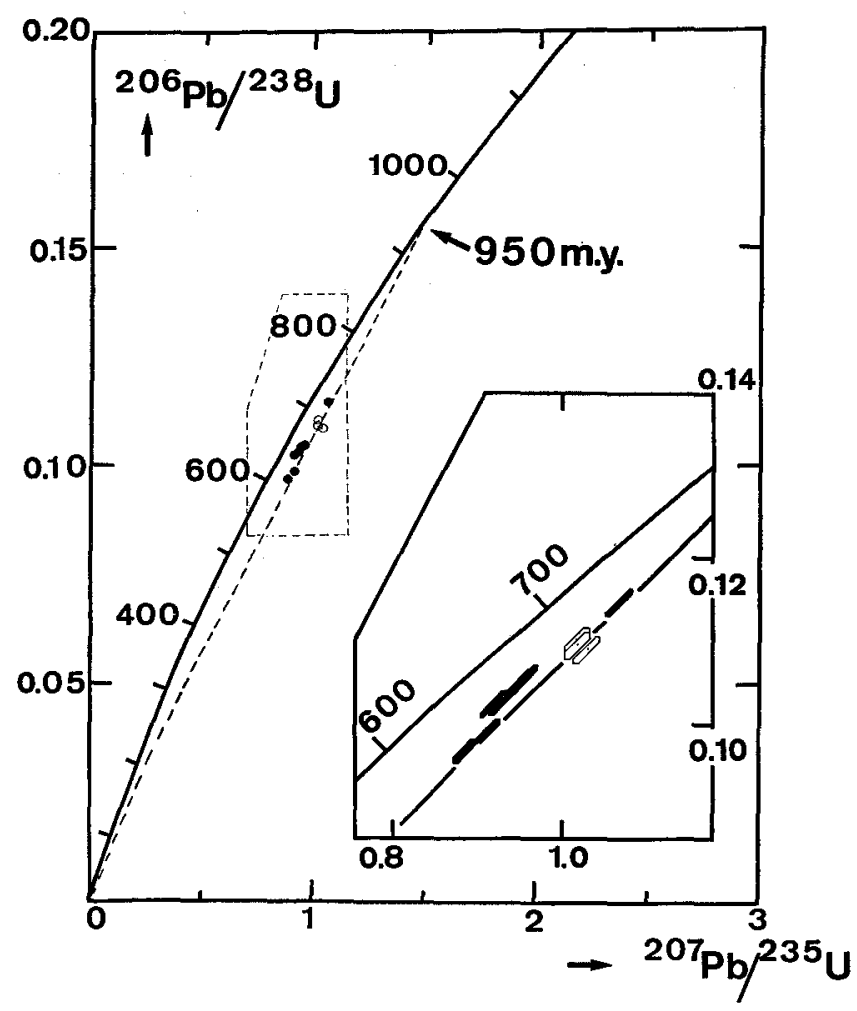

Fig. 10. Concordia diagram showing results of various zircon fractions obtained from augen granites GGU 103811 (open symbols) and GGU 136611 (solid symbols). The dashed line is a trajectory for zircons crystallised $950 \mathrm{~m}$.y. ago that have lost $\mathrm{Pb}$ continuously (Tilton, 1960).

The size of the symbols in the enlarged inset corresponds to the analytical errors.

\section{References}

Chadwick, B. 1971: Preliminary account of the geology of south-east Renland, Scoresby Sund, East Greenland. Rapp. Grønlands geol. Unders. 34, $32 \mathrm{pp}$.

Hansen, B. T., Oberli, F. \& Steiger, R. H. 1973: The geochronology of the Scoresby Sund area. Progress report 4: $\mathrm{Rb} / \mathrm{Sr}$ whole rock and mineral ages. Rapp. Grønlands geol. Unders. $58,55-58$.

Henriksen, N. \& Higgins, A. K. 1971: Preliminary results of mapping in the crystalline complex around Rypefjord and Rødefjord, and on northern Milne Land, Scoresby Sund, East Greenland. Rapp. Grønlands geol. Unders. 37, 5-18.

Oberli, F. \& Steiger, R. H. 1973: U-Pb age determinations on zircons and monazites from a migmatite area on Bjørneøer, Scoresby Sund, East Greenland. A preliminary report. Rapp. Grønlands geol. Unders. 58, 63-74. 
Steiger, R. H. \& Henriksen, N. 1972: The geochronology of the Scoresby Sund area. Progress report 3: Zircon ages. Rapp. Grønlands geol. Unders. 48, 109-114.

Tilton, G. R. 1960: Volume diffusion as a mechanism for discordant lead ages. J. geophys. Res. 65, 2933-2945.

Institut für Kristallographie und Petrographie,

Eidg. Technische Hochschule,

Sonneggstrasse 5 ,

8006 Zürich,

Switzerland. 